\title{
Nigella damascena L. Bitkisinde Farklı Gübre Uygulamalarının Fenolojik Özellikler Üzerine Etkileri
}

\author{
Funda Ulusu $^{1 *}$, Ali Şahin ${ }^{2}$ \\ ${ }^{1}$ Karamanoğlu Mehmetbey Üniversitesi, Teknik Bilimler Meslek Yüksekokulu, Organik Tarım Programı, Karaman, Türkiye (ORCID: 0000-0002-0321-2602) \\ ${ }^{2}$ Karamanoğlu Mehmetbey Üniversitesi, Sağlık Bilimleri Fakültesi, Hemşirelik Bölümü, Karaman, Türkiye
}

(İlk Geliş Tarihi 20 Ocak 2020 ve Kabul Tarihi 22 Şubat 2020)

(DOI: 10.31590/ejosat.677606)

ATIF/REFERENCE: Ulusu, F \& Şahin, A. (2020). Nigella damascena L. Bitkisinde Farklı Gübre Uygulamalarının Fenolojik Özellikler Üzerine Etkileri. Avrupa Bilim ve Teknoloji Dergisi, (18), 171-178.

$\ddot{O} \mathbf{z}$

Bu çalışma Şam çörekotu (Nigella damascena L.) bitkisine farklı sıvı gübre çeşitlerinin (organik, vermikompost ve sentetik gübre) farklı konsantrasyonlarda (yarısı, öneri, iki katı) uygulanmasının bitkinin çıkış süresi, çiçeklenme süresi ve vejetasyon süresi üzerine olan etkileri incelenmiştir. Çalışma tesadüfi deneme desenine göre 2018-2019 döneminde Karamanoğlu Mehmetbey Üniversitesi Araştırma Serası'nda saksılarda gerçekleştirilmiştir. Kontrol grubu ile birlikte 9 farklı uygulama grubu oluşturularak analizler 4 tekrarlı olarak yapılmıştır. Gübreler ekim öncesinde tohumlara, filizlendikten sonra (10-15cm uzunluğunda iken) ve çiçeklenme dönemi olmak üzere 3 kez uygulanmıştır. Elde edilen bulgulara göre gübre uygulama grupları içerisinde en hızlı çıkış ve çiçeklenmeyi sağlama ve ilk hasat organik iki katı (600-1200mL/da) grubunda görülmüştür. En geç çıkış ve çiçeklenmenin kimyasal (sentetik) öneri (2-3L/da) grubunda, en uzun vejetasyon süresinin (son hasat) ise kimyasal iki katı (4-6L/da) uygulamasında olduğu görülmüştür. Kontrol grubuna kıyasla tüm gübre uygulamalarının bitkinin fenolojik özellikleri üzerinde sürelerin kısalmasına etki ettiği gözlemlenmiştir.

Anahtar Kelimeler: Nigella damascena, Gübre, Fenolojik Özellikler

\section{Effects of Different Fertilizer Applications on Phenological Properties of Nigella damascena $\mathrm{L}$.}

\begin{abstract}
In this study, the effects of different liquid fertilizers, (organic, vermicompost and synthetic fertilizer) in different concentrations (half, recommended, twice) to the black cumin seed (Nigella damascena L.), on the emergence, flowering and vegetation period of the plant were investigated. The study was carried out in pots in Karamanoğlu Mehmetbey University Research Greenhouse in 2018-2019 period according to completely randomized plot design. Along with the control group, 9 different application groups were created and analyzes were performed in 4 replicates. Fertilizers were applied to the seeds 3 times before planting, after sprouting (when 10-15cm long) and flowering period. According to the findings; it was observed that among the fertilizer application groups the fastest emergence and flowering and the first harvest organic twice group $(600-1200 \mathrm{~mL} / \mathrm{da})$, the latest emergenceand flowering group was in the chemically recommended group (2-3 L/da), and the longest vegetation period (last harvest) was in the chemical twice concentration application group (4-6 L/da). Compared to the control group, it was observed that all fertilizer applications affect the shortening of the time on the phenological properties of the plant.
\end{abstract}

Keywords: Nigella damascena, Fertilizer, Phenological Properties.

\footnotetext{
${ }^{*}$ Sorumlu Yazar: Karamanoğlu Mehmetbey Üniversitesi, Teknik Bilimler Meslek Yüksekokulu, Organik Tarım Programı, Karaman, Türkiye, ORCID: 0000-0002-0321-2602, fulusu@kmu.edu.tr
} 


\section{Giriş}

Tıbbi ve aromatik bitkiler yüzyıllar boyunca geleneksel halk hekimliğinde hastalıkların tedavisinde kullanılmıştır ve günümüzde üretilen ilaçlar için önemli bir kaynak oluşturmaya devam etmektedir. Dünyanın \%80’i bitkisel temelli alternatif ilaç sistemine dayanmaktadır. Türkiye'nin özellikle tıbbi ve aromatik bitkiler açısından zengin bir floraya sahip olması farmakoloji alanında kullanılacak bitki sayısını ve çeşitliliğini de arttırmakla birlikte Türkiye'nin jeostratejik önemini güçlendirmektedir (Artukoğlu ve ark., 2002).

Türkiye'de yetiştirilerek katma değer yaratılmasını sağlayan ve alternatif tıp çalışmalarında sıklıkla kullanılan bu bitkilerden bazıları; çörekotu, safran, adaçayı, lavanta, semizotu, dereotu, çay, rezene, anason, kişniş, nane, kimyon, fesleğen, çemen, şerbetçi otu, kırmızıbiberdir. Ayrıca ülkemizde endemik bitkilerde dahil olmak üzere doğal olarak yetişen pek çok bitkinin tıbbi ve aromatik değeri oldukça yüksektir (Baydar, 2009).

Dünyada yayılış gösteren 300'den fazla çiçekli bitki familyası bulunmaktadır (Heywood, 1979). Bu familyalardan Ranunculaceae (Düğünçiçeğigiller) çoğunlukla otsu ve tek yıllık ya da uzun ömürlü olup tırmanıcı özellik gösteren pek çok tıbbi ve aromatik bitki türlerine sahiptir. Bunlardan Nigella cinsi farmakolojik özellikte olup aynı zamanda baharat olarakta dünya çapında kullanılmaktadır ve 20 kadar tür bulundurmakla birlikte yaklaşık 15 kadarı ülkemizde yetişmektedir (Başer, 2010; Ayhan, 2012). Nigella cinsine ait olan 3 tür Nigella sativa, Nigella damascena ve Nigella arvensis tohumları halk hekimliğinde ve baharat bitkisi olarak yoğun bir şekilde kullanılmaktadır (Baytop, 1984).

Nigella damascena L. (Şam çörekotu), Ranunculaceae (Düğünçiçeğigiller) familyasına ait tek yıllık, 20-50 cm büyüyebilen çiçekli, otsu ve değerli tıbbi-aromatik bir bitki olup kumlu-tınlı topraklarda iyi gelişebilmektedir. Çiçekleri genellikle mavi renge sahip olmakla birlikte beyaz ve pembe renkli de olabilmesinden ötürü genellikle süs bitkisi olarak yetiştirilmektedirler (Kökdil ve ark. 2006). Anavatanı, Kuzey Afrika ve Güneybatı Asya olup özel ismi Suriye-Şam (Damascus) ilinden gelmektedir. Özellikle Güney Avrupa ve Yakın Doğu'da en çok kullanılan Nigella türlerinden olup geleneksel Doğu tıbbında birçok hastalığın tedavisinde (Alamgir, 2017; Fico et al., 2004), ayrıca kendine has aromasından dolayı Asya kültürlerinde gastronomi alanında sıklıkla kullanılmaktadır. Yetiştirilmesi generatif olup tohumları N.sativa'nın tohumlarına benzemekte siyah renkte ve küçüktür.

Nigella damascena L. tohumlarında değişik miktarlarda değerli uçucu yağlar başta $\beta$-elemene, germacrene A, Damascenine bileşenlerinin yanı sıra $\alpha$-pinene, $\beta$-pinene, myrcene, p-cymene, limonene, vb. yer almaktadır (Fico ve ark., 2003, Wajs ve ark., 2009, Sieniawska ve ark., 2018). Ayrıca sabit yağlar, proteinler, alkoloidler, flavonoidler ve saponinler içermektedir (Fico ve ark. 2000; Fico ve ark., 2001; Sajfrtova, 2014; Farag ve ark.,2014). \%0,5 oranında uçucu yağ taşıyan bu bitkide uyuşturucu özelliğine sahip "Damascenine" N.damascena L. türüne ait bir alkoloitdir. Tohumların yapısında bulunan bu uçucu yağların antihistaminik, analjezik, antitümör, antimiktobiyal, antienflamatuar, antipiretik gibi önemli farmakolojik etkilerinden dolayı tıbbi ve ticari açıdan da değerli olan tıbbi bir bitkidir (Yao ve ark., 2008; Sieniawska ve ark., 2018; Sieniawska ve ark., 2019; Bekemeier ve ark., 1967; Fico et al., 2004).

Gübreler, bitkisel üretim faaliyetlerinde verimliliği arttırmak amacıyla toprağa veya doğrudan bitkiye uygulanan, aynı zamanda bitkiler için zorunlu olan doğal ya da kimyasal maddelerdir (Merriam-Webster, 2016). Bitkilerde gerçekleşen biyolojik ve fizikokimyasal reaksiyonlarda bitki besin elementlerinin rolü büyük olup büyüme ve gelişme döneminde toprakta miktarı azalan veya kaybedilen besin elementleri karşılanmadığı taktirde mahsüller büyüyemez ya da ürünlerden iyi verim alınamaz. Bu yüzden azalan besin elementlerinin tekrardan toprağa aktarılması yönünde gübreler kullanılmaktadır.

Çörekotu bitkisinde fenolojik, morfolojik, verim-kalite özelliklerini çevresel faktörlerin ve sulama miktarı, gübreleme çeşidi-miktarı, ekim zamanı-sıklığı, tohum miktarı gibi farklı yetiştirme tekniklerinin uygulanmasının önemli düzeyde etkilediği yapılmış birçok çalışmayla belirtilmiştir (Green ve ark., 1997; Özel ve Demirbilek, 2000; Telci,1995; Özgüven,1989; Tuncturk ve ark., 2012; Toncer ve Kizil, 2004; Forouzandeh, 2014).

Nigella damascena Türkiye'de de endemik olarak yetişen ve verimi en yüksek alınan tür olmasına rağmen $N$. sativa'ya oranla daha az araştırılmış bir türdür. Şam çörekotunun gübre uygulamasına gösterdiği hassasiyeti incelemek ve yetiştiriciliğine katkı sağlamak amacıyla bu çalışma gerçekleştirilmiştir.

Şam Çörek otu (Nigella damascena L.) yetiştiriciliğinde uygun gübre çeşidi ve miktarının çıkış süresi, çiçeklenme süresi ve vejetasyon süresi gibi bazı fenolojik özelliklere etkisinin araştırıldığı bu çalışma Karamanoğlu Mehmetbey Üniversitesi araştırma serasında 20182019 vejetasyon döneminde yürütülmüştür.

Çalışmamızda gübreler öncesinde tohuma, ekim sonrasında ise vejetatif ve çiçeklenme döneminde uygulanmıştır.

\section{Materyal ve Metot}

\subsection{Tohumların yüzey sterilizasyonu}

Araştırma materyali olarak kullanılacak N. damascena tohumları (100 g) Vilmorin Garden firmasından (İstanbul, Türkiye) temin edilmiştir. Tohumlar ekimi yapılmadan önce yüzey sterilizasyonuna tabi tutulmuştur. Yüzey sterilizasyonu \%1'lik sodyum hipoklorit $(\mathrm{NaClO})$ çözeltisinde 1 dakika bekletildikten sonra steril saf su ile yıkanarak yapılmıştır. 


\subsection{Nigella damascena $\mathbf{L}$. Yetiştirilmesi ve Gübreleme}

Tohumlar yüzey sterilizasyonları yapıldıktan sonra, $1 \mathrm{~L}$ suya $100 \mathrm{~mL}$ gübre olacak şekilde 6 saat farklı gübrelerde ki sularda bekletilerek, yarı yarıya torf ve bahçe toprağı karıştırılıp, her saksı 4 tekerrürlü olacak şekilde tesadüf parselleri deneme desenine göre Mart 2018'de saksılara ekimi yapılmış olup Karamanoğlu Mehmetbey Üniversitesi araştırma serasında $\left(25-30{ }^{\circ} \mathrm{C}\right.$ 'de, yeterli 1şı ke nem koşullarında) 3-4 günde bir sulanarak yetiştirilmiştir.

Denemede 3 farklı gübre (sıvı sentetik, sıvı organik, sıvı vermikompost), 3 değişik oranda uygulanmış olup kontrol grubuyla birlikte toplamda 10 farklı uygulama grubu oluşturulmuştur. Uygulanan gübrelerin çeşit ve miktarları Tablo 1'de gösterilmişstir.

Saksılarda çimlenme gerçekleşip bitkilerin yaklaşık olarak \%80'inde bitki boyları 10-15 cm uzunluğuna eriştikten sonra toprağa ilk gübre uygulamaları (yarısı, önerilen ve iki katı) gerçekleştirilmiştir. Toprağa 2. gübre uygulaması ise bitkilerin \%50'den fazlası çiçeklenmeye başladığı dönemde, 1. gübre uygulamasıyla aynı oranda (yarısı, önerilen ve iki katı) yapılmıştır.
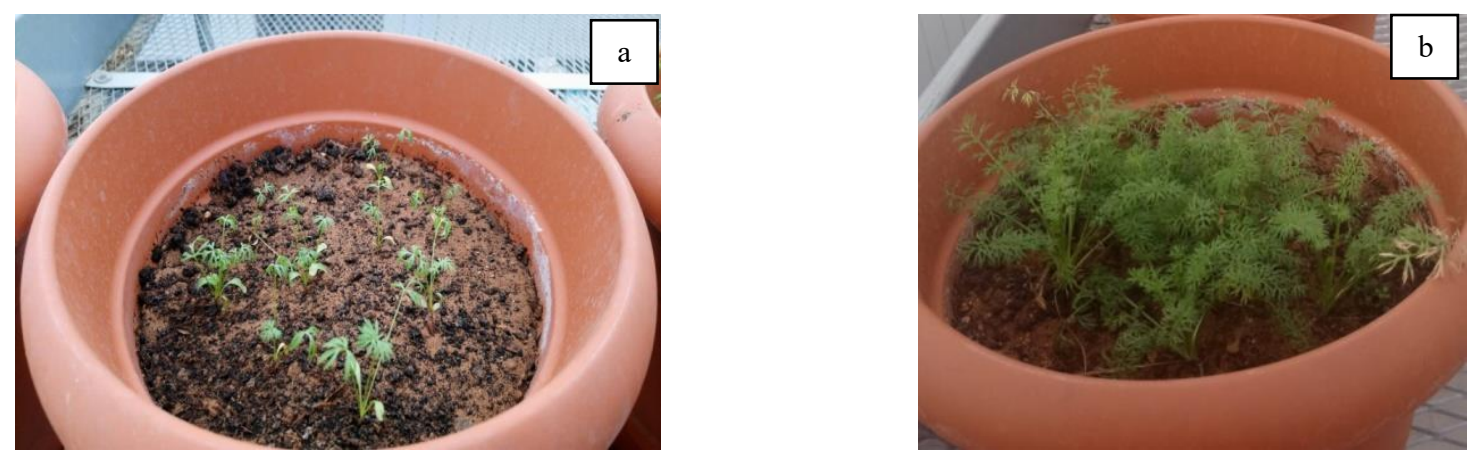

Şekil1. N. damascena çıkış(a), 10-15 cm uzunluğu(b)
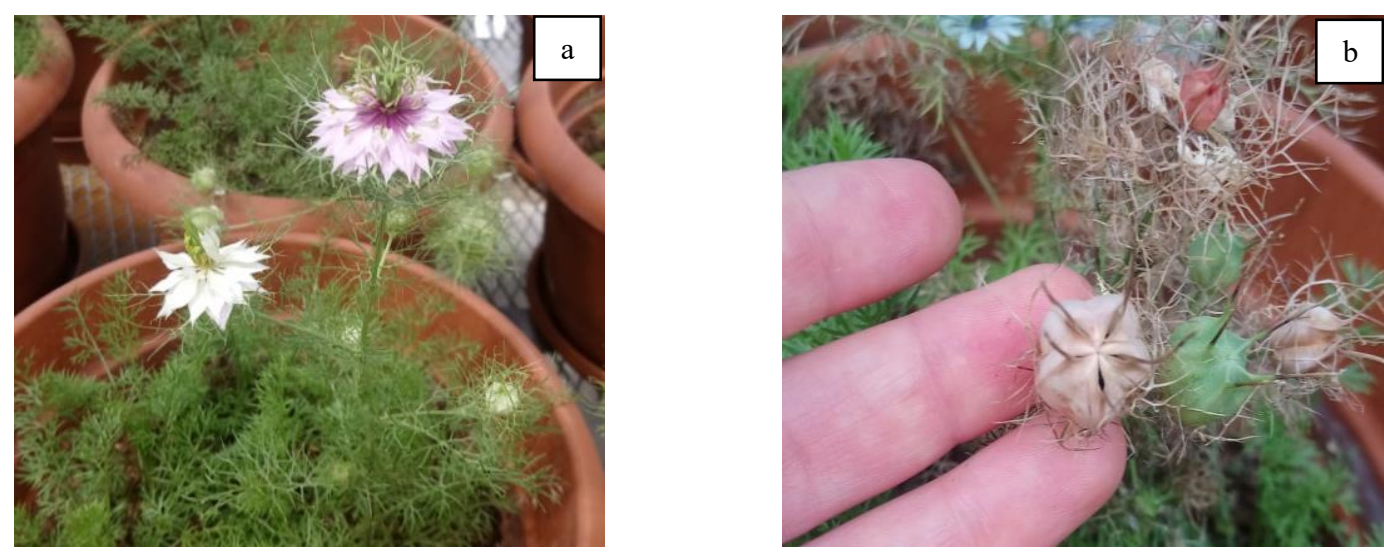

Şekil2. N. damascena çiçeklenme(a), olgunlaşma(b) 
Tablo 1. Gübre çeşit ve miktarları

\begin{tabular}{|c|c|c|c|c|c|}
\hline Uygulama No & Uygulama Adı & Kimyasal Bileşimi & \multicolumn{3}{|c|}{ Uygulama Dozajı } \\
\hline 1 & Negatif kontrol & & Yarisı & Önerilen & İki katı \\
\hline 2 & $\begin{array}{ll}\text { Siv1 } & \text { Sentetik } \\
\text { gübre } & \end{array}$ & $\mathrm{N}: \mathrm{P}: \mathrm{K}(\% 7: 7: 7)$ & $1-1,5 \mathrm{~L} / \mathrm{c}$ & $2-3 \mathrm{~L} / \mathrm{da}$ & $4-6 \mathrm{~L} / \mathrm{da}$ \\
\hline 3 & $\begin{array}{l}\text { Sıv1 Organik } \\
\text { gübre (Bitkisel } \\
\text { kökenli) }\end{array}$ & $\begin{array}{l}\text { Toplam organik madde: } \\
\text { \%45 } \\
\text { Organik C: \%19,5 } \\
\mathrm{N}: \% 3 \\
\mathrm{~K}_{2} \mathrm{O}: 7\end{array}$ & $\begin{array}{l}150-300 \\
\mathrm{~mL} / \mathrm{da}\end{array}$ & $300-600 \mathrm{~mL} / \mathrm{da}$ & $600-1200 \mathrm{~mL} / \mathrm{da}$ \\
\hline 4 & $\begin{array}{l}\text { Sivi } \\
\text { Vermikompost } \\
\text { gübresi } \\
\text { (Bitkisel ve } \\
\text { hayvansal } \\
\text { kökenli) }\end{array}$ & $\begin{array}{l}\text { Toplam organik madde: } \\
\% 5 \\
\mathrm{~N}: \% 1 \\
\text { Hümik+fülvikasit: } \% 10\end{array}$ & $\begin{array}{l}0,75- \\
1 \mathrm{~L} / \mathrm{d} \\
\mathrm{a}\end{array}$ & $1,5-2 \mathrm{~L} / \mathrm{da}$ & $3-4 \mathrm{~L} / \mathrm{da}$ \\
\hline
\end{tabular}

Denemede fenolojik özellik olarak çıkış süresi (gün), çiçeklenme süresi (gün) ve vejetasyon süresi (gün) gözlem ve ölçümleri Telci (1995) ve Akgören (2011)'in belirttiği yöntemlere göre yapılmıştır.

\section{3. İstatistiki analiz}

Kontrol ve uygulama gruplarındaki farklılıklar Duncan çoklu aralık testine göretek yönlü varyans analizi (one-way ANOVA) ile analiz edilerek, $\mathrm{P}<0,05$ önemlilik değerinde hesaplanmıştır. Çalışmada her bir grup için 4 tekrar yapılmıştır (n=4) (Duncan, 1955).

\section{Araștırma Sonuçları ve Tartıșma}

\section{1. Çıkış süresi (gün)}

Çıkış süresi, tohumların ekimden sonra her saksıda \%70-80 oranında çıkışın gerçekleştiği tarihe kadar geçen süre olarak belirlenir (Telci, 1995). Çalışmada 18.10.2018 tarihinde her bir saksıya ekimi yapılan çörekotu tohumları 30.10.2018 ve 16.11.2018 tarihleri arasında çıkışın olduğu, böylece çimlenme süresinin 12-28 gün aralığında değiştiği gözlemlenmiştir. Uygulama grupları arasında çıkış süresi açısından en hızlı çimlenmenin organik iki katı uygulamasında olduğu (12 gün), bunu vermikompost iki katı ve kimyasal iki katı gruplarının (14 gün) takip ettiği, en geç çimlenmenin ise kontrol grubunda (28 gün) olduğu görülmüştür. Uygulanan gübrelerin besin element oranlarının değişikliği çıkış performansı üzerine etki etmiş ve istatistiksel anlamda da farklılığa neden olmuştur. Şekil 3 'te gruplara ait ortalama çıkış süreleri verilmiştir.

Yapılan diğer çalışmalarda Selicioğlu, (2018) bu sürenin 17-25 gün arasında değiştiği ve en geç çimlenmeninde 25 . günle $N$. damascena türünde olduğunu, Telci, (1995) ise 15-16 günde çimlenmenin tamamlandığı belirtmiştir. Bu çalışmadan elde edilen sonuçların hem Selicioğlu, (2018) hem de Telci (1995) sonuçları ile uyum içerisinde olduğu görülmüştür.

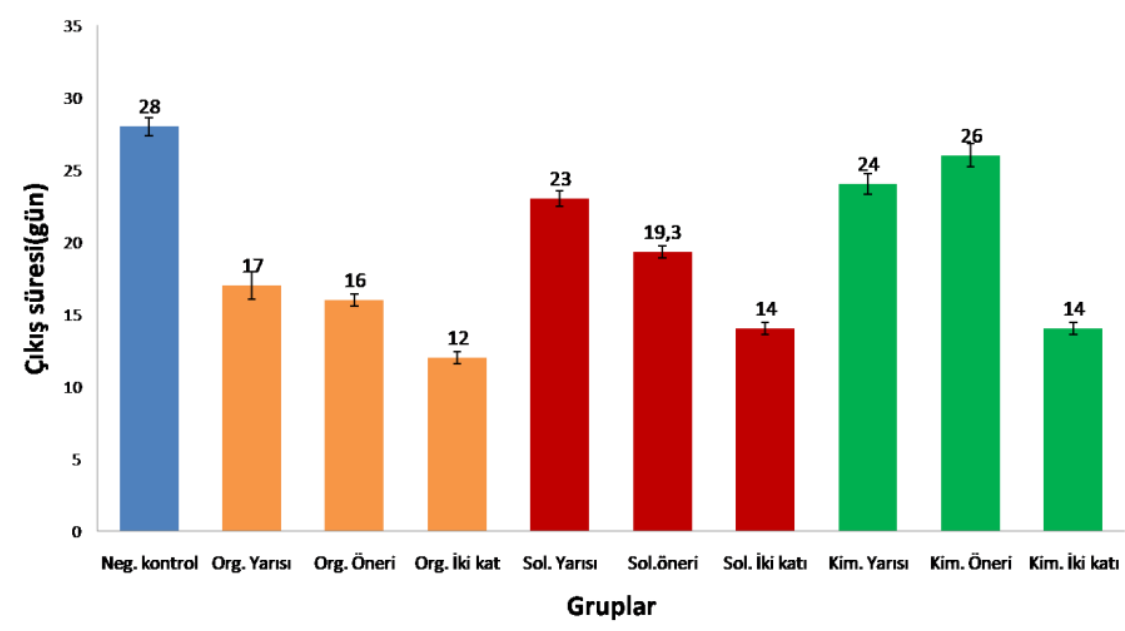

Şekil 3. Gruplara ait ortalama çıkış süreleri 


\section{2. Çiçeklenme süresi (gün)}

Ekim tarihi ile saksıdaki bitkilerin \%50'den fazlasının çiçeklendiği zaman arasındaki gün sayısı olarak ifade edilir (Telci, 1995). Çalışmada çiçeklenme süresi 93-134 gün arasında değişmekle birlikte ilk çiçeklenme organik iki katı gübre uygulamasında olup sonra sırasıyla vermikompost iki katı ve kimyasal iki katı gruplarında meydana gelmiştir. Uygulama grupları arasında organik gübrenin en erken çiçeklenmeye yol açtığı, bunu vermikompost gübre gruplarının takip ettiği, en geç çiçeklenmenin ise kontrol ve kimyasal öneri grubunda olduğu görülmüştür. Kontrol-kimyasal öneri grupları (a) ve organik yarısı-organik öneri (d) grupları istatistiksel anlamda farklı olmadığı görülmüştür. Fakat diğer gruplar arasındaki çiçeklenme sürelerinin değişkenliği istatistiki açıdan önemli bulunmuştur $(\mathrm{P}<0.05)$.

Çalışmanın kışlık dönemde gerçekleştirilmiş olması çiçeklenme süresinin uzamasına neden olmuştur. Gruplara ait ortalama çiçeklenme süreleri Şekil 4'te verilmiştir.

Tektaş (2015) 139 gün, D’Antuono (2002) 55-100 gün, Selicioğlu (2018) 54-86 gün, Akgören (2011) 55-92, Taq1 (2013), yazlık ekimde 70-73 gün arasında kışlık ekim ise 170-180 gün arasında değişiklik gösterdiğini belirtmişlerdir.

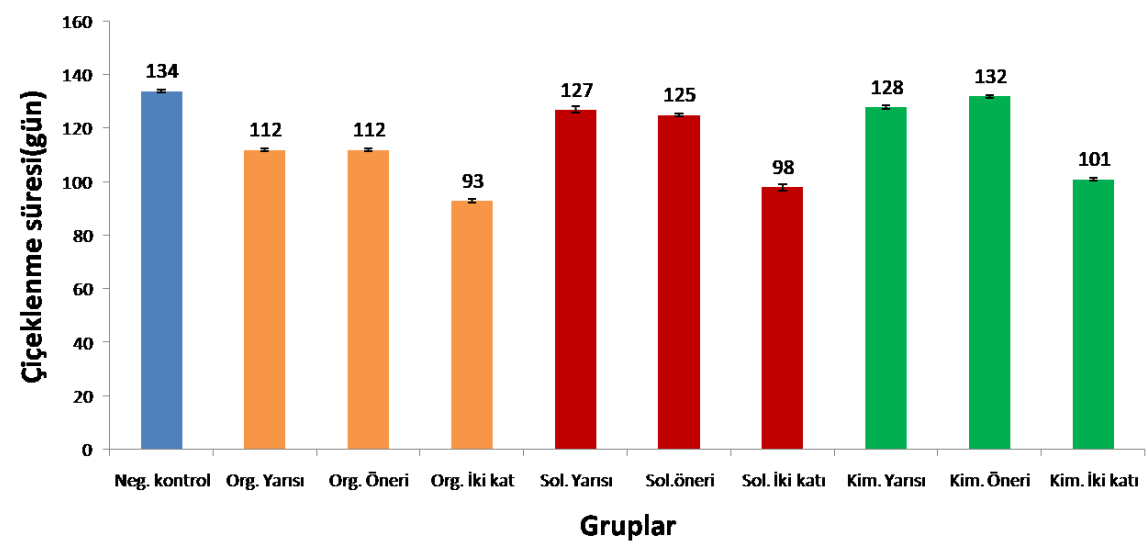

Şekil 4. Gruplara ait ortalama çiçeklenme süreleri

\subsection{Vejetasyon süresi (gün)}

Her saksıda çıkışın gerçekleştiği tarihten itibaren, hasat tarihine kadar geçen süre, vejetasyon süresi olarak belirlenmektedir (Telci, 1995; Akgören, 2011). Çalışmada kapsüllerin olgunlaşma tarihi (hasat) ilk ve son olgunlaşma süresi olmak üzere 2’ye ayrılmıştır. İlk olgunlaşma organik iki katı grubunda (167gün) gerçekleşmiş ve her uygulama grubu farklı vejetasyon sürelerine sahip olmuştur. İlk olgunlaşma süresi 167-231 gün, son olgunlaşma süresi ise 223-309 gün arasında değişmektedir. Gruplardaki ortalama vejetasyon süreleri (ilk olgunlaşma-hasat ve son olgunlaşma-hasat) Şekil 5 'te verilmiştir.

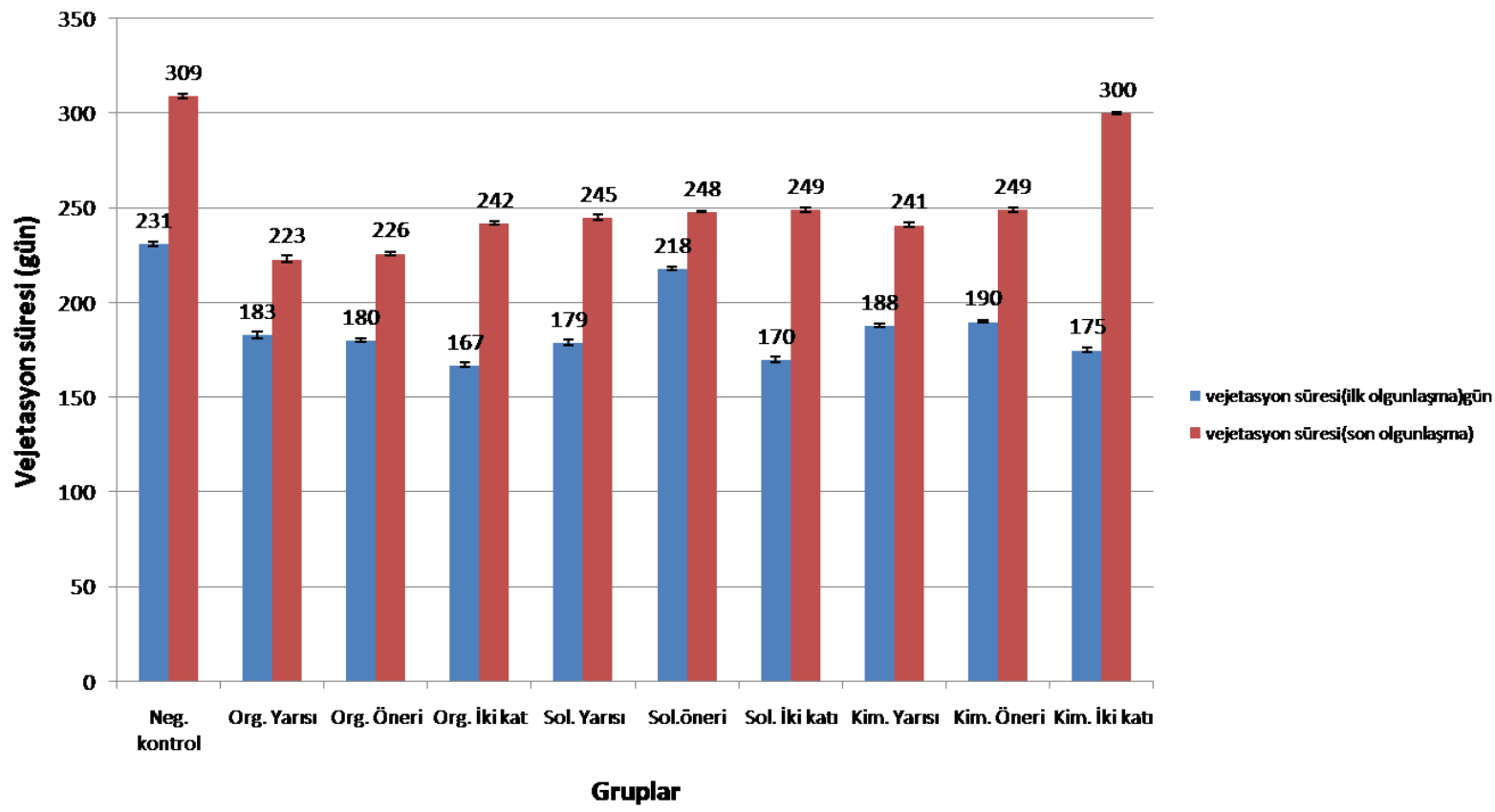

Şekil 5. Gruplara ait ortalama vejetasyon süreleri 
Tablo 2. Çıkış süresi (gün), çiçeklenme süresi (gün), Vejetasyon süresi (gün)

\begin{tabular}{|l|c|c|c|c|}
\hline Gruplar & Çıkıs süresi (gün) & $\begin{array}{l}\text { Çiçeklenme } \\
\text { süresi (gün) }\end{array}$ & $\begin{array}{l}\text { Vejetasyon süresi } \\
\text { (ilk olgunlaşma) } \\
\text { gün }\end{array}$ & $\begin{array}{l}\text { Vejetasyon süresi } \\
\text { (son olgunlaşma) } \\
\text { gün }\end{array}$ \\
\hline Neg. Kontrol & $28 \pm 0.62^{\mathrm{a}}$ & $134 \pm 0.48^{\mathrm{a}}$ & $231 \pm 1.35^{\mathrm{a}}$ & $309 \pm 1.35^{\mathrm{a}}$ \\
\hline Org. Yarı1 & $17 \pm 0.94^{\mathrm{e}}$ & $112 \pm 0.53^{\mathrm{d}}$ & $183 \pm 1.82^{\mathrm{d}}$ & $223 \pm 1.83^{\mathrm{g}}$ \\
\hline Org. Öneri & $16 \pm 0.40^{\mathrm{e}}$ & $112 \pm 0.59^{\mathrm{d}}$ & $180 \pm 0.81^{\mathrm{e}}$ & $226 \pm 0.81^{\mathrm{f}}$ \\
\hline Org. İki kat & $12 \pm 0.40^{\mathrm{g}}$ & $93 \pm 0.81^{\mathrm{g}}$ & $167 \pm 1.18^{\mathrm{h}}$ & $242 \pm 1.18^{\mathrm{e}}$ \\
\hline Sol. Yarıs1 & $23 \pm 0.62^{\mathrm{c}}$ & $127 \pm 1.22^{\mathrm{bc}}$ & $179 \pm 1.22^{\mathrm{e}}$ & $245 \pm 1.29$ \\
\hline Sol. Öneri & $19 \pm 0.53^{\mathrm{d}}$ & $125 \pm 0.54^{\mathrm{c}}$ & $218 \pm 1.02^{\mathrm{b}}$ & $248 \pm 0.59^{\mathrm{c}}$ \\
\hline Sol. İki kat1 & $14 \pm 0.58^{\mathrm{f}}$ & $98 \pm 1.08^{\mathrm{f}}$ & $170 \pm 1.42^{\mathrm{g}}$ & $249 \pm 1.25^{\mathrm{c}}$ \\
\hline Kim. Yarıs1 & $24 \pm 0.70^{\mathrm{c}}$ & $128 \pm 0.57^{\mathrm{b}}$ & $188 \pm 1.03^{\mathrm{c}}$ & $241 \pm 1.32^{\mathrm{e}}$ \\
\hline Kim. Öneri & $26 \pm 0.81^{\mathrm{b}}$ & $132 \pm 0.62^{\mathrm{a}}$ & $190 \pm 0.57^{\mathrm{c}}$ & $249 \pm 1.26^{\mathrm{c}}$ \\
\hline Kim. İki kat1 & $14 \pm 0.67^{\mathrm{f}}$ & $101 \pm 0.64^{\mathrm{e}}$ & $175 \pm 1.05^{\mathrm{f}}$ & $300 \pm 0.57^{\mathrm{b}}$ \\
\hline
\end{tabular}

*Veriler ortalama \pm standart sapma $(\mathrm{n}=4)$ olarak ifade edilmiştir. Uygulama grupları arasındaki farklılıklar aynı sütundaki farklı harflerle ifade edilmiştir $(\mathrm{p}<0.05)$.

Çörek otu bitkisinde vejetasyon süresi ekim zamanına (yazlık- kışlık) göre değişmekte olup kış döneminde yetiştirilen çörek otunun vejetasyon süresinin yaz döneminde yetiştirilene göre daha uzun olduğu görülmektedir (Ertaş, 2016). Literatürde N.damascena türünün N. sativa türünden daha uzun vejetasyon süresine sahip olduğu bilinmektedir (Zaitoun, 2008; Ertaş, 2016). Ertaş (2016) çalışmasında kışlık ekim sonrası vejetasyon süresinin 213-255 gün, yazlık ekimde ise 108-151 gün arasında olduğu ve en uzun vejetasyon süresinin N.damascena 'ya ait olduğu belirtilmiş̧ir. Kışlık dönemde gerçekleştirilen bu çalışmada elde edilen veriler Ertaş (2016) ile uyum göstermektedir.

Gübre uygulamalarının vejetasyon süresine etkisi değerlendirildiğinde organik gübre uygulama grupları arasında en erken olgunlaşma ve en uzun vejetasyon süresi, organik iki katı grubunda bulunmuştur. En geç ilk hasat ve en kısa vejetasyon süresi Organik Yarısı grubuna aittir. Vermikompost gübre uygulamalarında en erken hasat ve en uzun vejetasyon süresi vermikompost iki katı grubunda, en geç ilk hasat vermikompost öneri uygulamasında görülmüştür. Kimyasal gübre uygulamalarında ise en erken hasat ve en uzun vejetasyon süresi kimyasal iki katı grubunda, en geç ilk hasat kimyasal öneri uygulamasında görülmüştür. Tüm uygulama grupları arasında ise en geç hasat ve en uzun vejetasyon süresi kontrol grubunda (309 gün) bulunmuştur. Böylece tüm gübre uygulama gruplarında toplam vejetasyon süresinin kısalmasına neden olduğu görülmüștür.

Bitkilerin vejetasyon sürelerinin uzunluğuna ışıklanma süresi, sıcaklık ve kalıtımsal özelliklerin etkili olduğu yapılmış pek çok çalışmayla desteklenmektedir (Sezek, 2014; Ertaş, 2016). Bununla birlikte özellikle gün uzunluğunun ve sıcaklığın optimum seviyenin altında olması bitkilerin vejetasyon sürelerinin uzamasına neden olmaktadır. Çalışmada gübre uygulamalarındaki doz artışı genel anlamda çörek otu bitkisi çıkış süresinin, çiçeklenme süresinin ve vejetasyon süresinin kısalmasına neden olduğu görülmüştür.

Yapılan diğer çalışmalarda tohumlu bitkilerde vejetasyon süresinin uzaması, olgunlaşmanın gecikmesiyle birlikte verim ve kalitenin de düşmesine yol açabildiği belirtilmiştir (Blade ve Baker 1991).

\section{Sonuç}

Bu çalışma Karamanoğlu Mehmetbey Üniversitesi araştırma serasında 2018-2019 vejetasyon döneminde Şam çörekotu (Nigella damascena L.) bitkisine 3 farklı sıvı gübrenin değiş̧ik dozlarda uygulanmasının fenolojik özellikler üzerine olan etkisi araştırılmışıtır. Elde edilen verilere göre özellikle organik ve vermikompost gübre uygulamalarının genel itibariyle çıkış, çiçeklenme ve vejetasyon sürelerini kısalttığı gözlemlenmiş olup, kimyasal gübre uygulamalarının kontrol grubuna yakın değerlere sahip olduğu görülmüştür. Bitki yetiştiriciliğinde vejetasyon süresinin uzaması hem bir dönem içerisinde alınabilecek mahsül sayısını azaltmakta hem de özellikle tohumlu bitkilerde geç olgunlaşmayla elde edilecek verim kalitenin azalmasına yol açmaktadır. Tarımda bitkisel üretimi arttırmak adına yoğun miktarda kullanılan kimyasal gübreler gerek insan sağlı̆̆ı üzerinde ki olumsuz etkilere neden olmakta gerekse ekosistemde ki sürdürülebilirliğin azalmasıyla (toprak tuzluluğunun artması ve ağır metal birikimi, $\mathrm{N}_{2} \mathrm{O}$-sera gazları oluşumu, sularda ki yapay ötrofikasyon, vb.) sonuçlanmaktadır. 
Bu manada tıbbi ve gastronomi alanında değerli olan çörek otu bitkisinin yetiştiriciliğinde uygulanan sentetik gübrelerden ziyade özellikle son yıllarda tüm dünyada önem kazanan doğa dostu organik ve vermikompost gübrelerinin uygun oranlarda kullanılması hem alınan verim ve kaliteyi arttıracak hem de sürdürülebilir bir tarım sistemine katkı sağlayacaktır.

\section{Teşekkür}

Bu çalışma Karamanoğlu Mehmetbey Üniversitesi Bilimsel Araştırma Projeleri Komisyonu tarafindan desteklenmiştir (BAP 03-D-

\section{Kaynakça}

Akgören, G. (2011). Bazı çörekotu (Nigella sativa L.) populasyonlarının tarımsal özellikleri [Agriculturalfeatures of someblackcumin (Nigella sativa L.) populations]. Eskişehir Osmangazi Üniversitesi Fen Bilimleri Enstitüsü - Tarla Bitkileri Anabilim Dalı Eskişehir.92S.

Alamgir, A. N. M. (2017). Therapeutic Use of Medicinal Plants and Their Extracts: Volume 1. Pharmacognosy.

Artukoglu, M., Uzmay, A., \& Olgun, A. (2002). An evaluation of medicinal and aromatic plant trade in the world, in the EU and in Turkey. Agro Food Industry Hi Tech, 13(6), 19-24.

Ayhan, B., (2012). Nigella sativa L. Bitkisi Üzerine Fitoterapötik Çalışmalar. Yüksek Lisans Tezi, Gazi Üniversitesi, Sağlık Bilimleri Enstitüsü. Ankara.

Başer, K.H.C. (2010). Çörek Otu (Nigella sativa). Bağbahçe dergisi, 32(3): 26-27.

Baydar, H. (2009). Trbbi ve Aromatik Bitkiler Bilimi ve Teknolojisi, Süleyman Demirel Üniversitesi Ziraat Fakültesi, Yayın No: 51, Isparta.

Baytop, T. (1984). Therapy with Medicinal Plants in Turkey. p. 480 (Past and Present). Publications of the Istanbul University. No.3255, Istanbul. (in Turkish).

Bekemeier, H., Leuschner, G., \& Schmollack, W. (1967). Antipyretic, antiedematous and analgetic effects of damascenin in comparison with acetylsalicylic acid and phenylbutazone. Archives internationales de pharmacodynamie et de therapie, 168(1), 199.

Blade, S. F., \& Baker, R. J. (1991). Kernel weight response to source-sink changes in spring wheat. Crop science, 31(5), 1117-1120.

Boni, U., \& Patri, G. (1977). Scoprire, riconoscere, usare le erbe. Fabbri Editori, 437.

D'Antuono, L. F., Moretti, A., \& Lovato, A. F. (2002). Seed yield, yield components, oil content and essential oil content and composition of Nigella sativa L. and Nigella damascena L. Industrial crops and products, 15(1), 59-69.

Duncan, D. B. (1955). Multiple range and multiple F tests. Biometrics, 11(1), 1-42.

D'Antuono, L. F., Moretti, A., \& Lovato, A. F. (2002). Seed yield, yield components, oil content and essential oil content and composition of Nigella sativa L. and Nigella damascena L. Industrial crops and products, 15(1), 59-69.

Ertaş, M.E. (2016). Tokat Kazova Ekolojik Koşullarında Kışlık Ve Yazlık Ekilen Çörek Otu (Nigella sp.) GenotiplerininAgronomik ve Kalite Özelliklerinin Belirlenmesi, Gaziosmanpaşa Üniversitesi, Fen Bilimleri, Enstitüsü Yüksek Lisans Tezi, 49s, Tokat.

Farag, M. A., Gad, H. A., Heiss, A. G., \& Wessjohann, L. A. (2014). Metabolomics driven analysis of six Nigella species seeds via UPLC-qTOF-MS and GC-MS coupled to chemometrics. Food chemistry, 151, 333-342.

Fico, G., Bader, A., Flamini, G., Cioni, P. L., \& Morelli, I. (2003). Essential oil of Nigella damascena L.(Ranunculaceae) seeds. Journal of Essential Oil Research, 15(1), 57-58.

Fico, G., Panizzi, L., Flamini, G., Braca, A., Morelli, I., Tomè, F., \& Cioni, P. L. (2004). Biological screening of Nigella damascena for antimicrobial and molluscicidal activities. Phytotherapy Research: An International Journal Devoted to Pharmacological and Toxicological Evaluation of Natural Product Derivatives, 18(6), 468-470.

Fico, G., Braca, A., Tomè, F., \& Morelli, I. (2000). Phenolic derivatives from Nigella damascena seeds. Pharmaceutical biology, 38(5), 371-373.

Fico, G., Braca, A., Tomè, F., \& Morelli, I. (2001). A new phenolic compound from Nigella damascena seeds. Fitoterapia, 72(4), 462463.

Forouzandeh, M., Karimian, M. A., \& Mohkami, Z. (2014). Effect of water stress and different types of organic fertilizers on essential oil content and yield components of Cuminum cyminum. Indian Journal of Fundamental and Applied Life Sciences, 4(3), 533-536.

Fournier, P. (1948). Le livre des plantes médicinales et vénéuses de France: 1.500 espèces par le texte et par l'image, d'après l'ensemble de nos connaissances actuelles (Vol. 25). P. Lechevalier.

Geren, H., Bayram, E., ve Ceylan, A. (1997). Çörek Otu (Nigellasativa L.)'nda Farklı Ekim Zamanlarının Ve Fosfor Gübresi Uygulamasının Verim ve Kaliteye Etkisi, Türkiye II. Tarla Bitkileri Kongresi Bildiri Kitabı, 2-5 Eylül, Samsun, 376-380.

Heywood, V. H., Moore, D. M., Dunkley, J., \& King, C. (Eds.). (1978). Flowering plants of the world (Vol. 336). Oxford: Oxford University Press.

Kökdil, G. (2006). Morphology And Stem Anatomy of Some Species of Genus. Ankara Üniversitesi Eczacllk Fakültesi Dergisi, 35(1), $19-41$.

Merriam-Webster.html. (2016). Retrieved from http://www.merriam-webster.com/dictionary/fertilizer.

Özel, A., \& Demirbilek, T. (2000). Harran Ovası kuru koşullarında bazı tek yıllık baharat bitkilerinin verim ve bazı agronomik özelliklerinin belirlenmesi. Harran Üniversitesi Ziraat Fakültesi Dergisi, 4(3-4), 21-32.

Özgüven, M. (1982). Çukurova Bölgesinde Bazı Tıbbi Bitkilerin Adaptasyonu Üzerinde Araştırmalar. IV. İlaç Hammaddeleri Toplantısl. Anadolu Üniversitesi Yaylnlarl, (30), 19-23.

Sajfrtova, M., Sovova, H., \& Karban, J. (2014). Enrichment of Nigella damascena extract with volatile compounds using supercritical fluid extraction. The Journal of Supercritical Fluids, 94, 160-164. 
Selicioğlu M. (2018). Kırşehir Ekolojik Koşullarında Çörek Otu (Nıgella Sp.) Populasyonlarının Bazı Tarımsal ve Kalite Özelliklerinin Belirlenmesi, Yüksek Lisans Tezi, Süleyman Demirel Üniversitesi Isparta.

Sezek, M., (2014). Farklı Ekim Zamanlarının Kişniş (Coriandriumsativum L.) Çeşitlerinin Verim, Verim Unsurları ve Uçucu Yağ Oranına Etkisi. Atatürk Üniversitesi, Fen Bilimleri Enstitüsü, Yüksek Lisans Tezi, Erzurum, 61s.

Sieniawska, E., Sawicki, R., Golus, J., Swatko-Ossor, M., Ginalska, G., \& Skalicka-Wozniak, K. (2018). Nigella damascena L. essential oil-a valuable source of $\beta$-elemene for antimicrobial testing. Molecules, 23(2), 256.

Sieniawska, E., Michel, P., Mroczek, T., Granica, S., \& Skalicka-Woźniak, K. (2019). Nigella damascena L. essential oil and its main constituents, damascenine and $\beta$-elemene modulate inflammatory response of human neutrophils ex vivo. Food and chemical toxicology, 125, 161-169.

Tektaş, E. (2015). Harran Ovası Koşullarında Birim Alandaki Tohum Sayısının Çörek Otu (Nigella sativa L.)'nun Verim ve Bazı Bitkisel Özelliklerine Etkisi, Yüksek Lisans Tezi, Harran Üniversitesi, Şanlıurfa.

Telci, İ. (1995). Tokat Şartlarında Farklı Ekim Sıklığının Çörek otu (Nigella sativa L.)'unda Verim, Verim Unsurları ve Bazı Bitkisel Özelliklerine Etkisi. Yüksek Lisans Tezi, Gaziosmanpaşa Üniversitesi, Tokat.

Toncer, O., \& Kizil, S. Ü. L. E. Y. M. A. N. (2004). Effect of seed rate on agronomic and technologic characters of Nigella sativa L. International Journal of Agriculture and Biology, 6(3), 529-532.

Tuncturk, R., Tuncturk, M., \& Ciftci, V. (2012). The effects of varying nitrogen doses on yield and some yield components of black cumin (Nigella sativa L.). Advances in Environmental Biology, 6(2), 855-858.

Wajs, A., Bonikowski, R., \& Kalemba, D. (2009). Different isolation methods for determination of composition of volatiles from Nigella damascena L. seeds. Natural product communications, 4(11), 1934578X0900401125.

Yao, Y. Q., Ding, X., Jia, Y. C., Huang, C. X., Wang, Y. Z., \& Xu, Y. H. (2008). Anti-tumor effect of $\beta$-elemene in glioblastoma cells depends on p38 MAPK activation. Cancer letters, 264(1), 127-134.

Zaitoun, S., Al-Ghzawi, A. A. M., Samarah, N., \& Alqudah, A. (2008). Comparative study in seed yield and flowers attractivity to bee visitors between Nigella Sativa L. and Nigella Damascena L. (Ranunculaceae) grown under semiarid conditions. Italian Journal of Agronomy, 125-130. 